\title{
'Milk from the purest place on earth': examining Chinese investments in the Australian dairy sector
}

\author{
Michaela Böhme ${ }^{1}$ (D) \\ Accepted: 12 September 2020 / Published online: 13 October 2020 \\ (c) The Author(s) 2020
}

\begin{abstract}
This article explores the emerging intersections between the shift towards higher quality food consumption in China and Chinese investment in overseas farmland. Based on an ethnographic study of a Chinese company acquiring one of Australia's largest dairy farms, the article argues that the linkage between imported Australian milk and perceptions of safety and quality has served as a powerful driver of Chinese investment in overseas farmland - a linkage that has largely been overlooked by literature on China's role in the global land rush. Drawing on the notion of 'quality imaginaries', the paper shows how images of Australian farmland as natural, pure, and geographically isolated have been mobilized by the investor company to position itself as provider of fresh, premium milk in the Chinese market. While such place-based qualities constitute a prized advantage, ironically, they also present a looming risk as the investor company struggles to reconcile fresh milk's perishability with the farm's location at the 'edge of the world'. Thus, the case study not only demonstrates how cultural meanings tied to food and eating shape the ways in which investors imagine land's affordances and possibilities but also draws attention to land's materiality as a factor that both facilitates and destabilizes investment in farmland.
\end{abstract}

Keywords Land imaginaries $\cdot$ Farmland investment $\cdot$ China $\cdot$ Australia $\cdot$ Quality

\section{Prologue}

On a mild summer day towards the end of December, I am sitting in a car with the farm manager of a large Australian dairy farm. As we drive past the lush pastures of the property, I can see small herds of Friesian and Jersey dairy cows, grazing peacefully under the steel blue sky. I have come here to learn more about one of the largest Chinese farmland investments that have occurred over the past few years in the Australian dairy sector. The farm manager, an experienced dairy farmer from the local community, has taken time out from her busy schedule to show me around the property. Frequently stopping along the way, the farm manager explains to me the new pasture management methods, organic dairying principles, and equipment upgrades that have been introduced since the farm was taken over by its new owners. As the day draws to an end, the farm manager points out that there is still one place I absolutely must see.

Michaela Böhme

michaelaboehme@uni-leipzig.de

1 Collaborative Research Centre 1199, Leipzig University, Leipzig, Germany
It is the most important part of the whole farm, she insists. We drive up one of the many hills, and a spectacular view across the ocean opens up before our eyes. 'This is literally the edge of the world' the farm manager explains to me, and, pointing to the weather station installed on top of the hill, 'the place where the cleanest air is, right up here. So, we actually boast the healthiest cows, breathing the healthiest air, producing the highest quality milk'. 'This', the farm manager concludes, 'is obviously a huge selling point in China, and some people will pay a premium for that'.

\section{Introduction}

In recent years, agro-industrial transformations in China's food sector have produced increasing uncertainties about food and a 'crisis of trust' in domestically grown food products (Hanser and Li 2015; Klein 2013; Yan 2012). As one food scandal after the other hits Chinese society, affluent Chinese consumers are increasingly 'opting out' (Hanser and Li 2015) of the Chinese food system in favor of imported foods from countries and places of production associated with higher levels of quality and safety. The growing 
demand for high-quality food has become a driving force behind Chinese investment in overseas farmland. In particular, countries such as Australia or New Zealand with a reputation for clean, green, and safe farming environments have become attractive locations for Chinese farmland investors seeking to tap into the growing demand for 'premium' food (Gooch and Gale 2018; KPMG 2013). Situating itself within the growing body of literature on the 'global land rush' and the financialization of food and farming, this paper takes the crisis of trust in China's domestic food sector as a starting point to examine the emerging intersections between shifting meanings of food quality and safety and growing flows of Chinese capital into Australian farmland. The paper argues that imaginaries of Australian farmland as natural and pure are being mobilized as key devices by investors to enhance perceptions of food quality and safety and, consequently, increase the profits investors can generate from the sale and export of foods produced in Australia. To substantiate this argument empirically, this paper focuses on a case study of Chinese investment in Australian dairy farming. Dairy foods have been embroiled in some of China's most egregious food scares, including the infamous 2008 melamine scandal and, hence, provide a case study par excellence how evolving consumer meanings of quality and safety intersect with the investment strategies of Chinese firms acquiring land in Australia.

To deepen our understanding of the emerging intersections between consumer demand for high-quality and safe food and investor interest in premium farmland and food production overseas, I will employ the concept of 'quality imaginaries'. Building on Cook and Crang's (1996) cultural materialist work on the imaginative geographies associated with food in constructing our 'worlds on a plate', I argue that the concept of quality imaginaries provides a useful analytical lens through which to examine how investors enhance and exploit perceptions of quality in food by linking food products to land imaginaries that emphasize the naturalness and purity of the farming environment. Following Appadurai's (1986) seminal work on 'the social life of things', social scientists have highlighted how the meanings and values of commodities are shaped by the social contexts in which commodities are embedded. Applying these insights to the world of food, Cook and Crang (1996) demonstrate how, by 'drawing on and adding to existing imaginaries of people and places' (ibid., p. 136), people ascribe meaning to food through the deployment of 'geographical knowledges' that link food commodities to particular places and their associated materialities and characteristics. For Cook and Crang, the meanings ascribed to food have both a cultural and an economic dimension, i.e., they 'are not only a matter of moral and cultural significance, but are also central in differentiating food products, their providers and consumers, and in adding value in markets in which there is intense pressure on profit margins' (ibid., p. 134). Building on these insights, I show how investors draw on land's biophysical materiality and local-environmental conditions of production-i.e., its soils, climate, atmosphere, topography, or location-to mobilize imaginaries of farmland as natural and pure and, hence, imbue the food that is produced there with meanings that speak to popular anxieties about the quality, safety, and healthiness of food. I also highlight how the material and locational characteristics of land not only feed into meanings of quality from which investors derive profits but, paradoxically, also impose a limit on the ability of investors to capture value from such quality imaginaries.

By exploring the intersections between farmland investments and the changing socio-cultural meanings of food quality in China, this paper seeks to make a two-fold contribution to the literature on the global land rush and the financialization of food and farming. First, from a theoretical point of view, the paper sheds light on the constitutive role of the cultural and symbolic meanings of food and food provisioning for the placement of new types of capital into farmland and agriculture. In contrast to the more classically informed political economy approaches to the land rush with their emphasis on the structuralist drivers of investment, a focus on the cultural meanings and imaginative geographies associated with 'quality' food helps illuminate how understandings of land and land's material-environmental characteristics shape the ways in which farmland is enrolled into strategies of investment and finance. Second, from an empirical point of view, this paper attempts to offer a new perspective on the role and characteristics of Chinese farmland investments within the land rush literature. While China's emergence as a new hub of investment capital into food and farming systems has been described in great detail in the context of developing or emerging economies (Oliveira 2018; Brautigam 2015; Oliveira and Schneider 2015; Brautigam and Zhang 2013), scholarship has paid scant attention to Chinese farmland investments in developed economies. In the Australian context, scholars have noted the growing significance of investment from China for Australia's agriculture sector as well as the concerns and controversies linked to it (Lawrence et al. 2019; Magnan 2018), but virtually no study to date has provided a fieldwork based analysis of the practices, devices, knowledges, and visions that underpin the activities of Chinese investors 'on the ground'. This paper seeks to address this gap by providing an ethnographic account of the actors and practices that arrange Chinese capital around quality imaginaries linking images of the naturalness and purity of Australian farmland with notions of high-quality, premium foods.

The data presented in this paper has been collected as part of an ongoing dissertation project and is drawn from interviews with investors, farm managers, industry associations, and regulators from the Australian and Chinese dairy 
sectors. Interviews were conducted between 2017 and 2018 during eight months of fieldwork in different locations in both Australia and China. I complement this information with an analysis of consumer-facing marketing materials and promotional literature collected from the website and WeChat ${ }^{1}$ account the investor company uses to market and sell milk from its Australian farm to Chinese consumers. To conceptually support the empirical material presented here, the paper starts with a brief overview of a few key insights from land rush research and combines these with perspectives from economic sociology and geography on "quality food'. It then provides a brief background on the development of China's dairy industry and the rise and significance of Chinese investments in overseas dairy farmland. Subsequent chapters draw on detailed examples from one Chinese investment project in Australia's dairy sector to highlight how meanings of quality in milk forge new linkages between Chinese sources of capital and Australian farmland. The final section discusses the theoretical implications of these findings for the land rush literature.

\section{Situating farmland investments within an economy of quality food}

Investments in farmland are on the rise. In the past decade, an extensive body of literature on the land rush in food and farming has documented how investors of all stripes, including pension funds, farmland investment funds, and agricultural and non-agricultural companies have acquired large swaths of farmland around the globe. Much of this literature has focused on the structural drivers behind investors' interest in farmland, such as growing demand for food, rising commodity prices, investment portfolio diversification, and speculative returns from rising farmland values (Edelman et al. 2013; Scoones et al. 2013; Wolford et al. 2013; Cotula 2012). More recently, a new generation of land rush research has brought a more constructivist approach to earlier perspectives grounded in political economy. These new contributions caution against an understanding of farmland investments as a 'totalizing' phenomenon and highlight the spatially and temporally uneven ways in which farmland is enrolled into circuits of capital (Visser 2017; Ouma 2014). Building on Li's (2014) seminal work on how farmland is

\footnotetext{
${ }^{1}$ WeChat is a mobile application that has become the most popular digital marketing and sales channel for companies selling consumer products in China. Consumers interested in a company's product can sign up to the company's WeChat account to receive product information and regular consumer updates, and to order products from the company's WeChat 'shop'. In many respects, WeChat has come to replace websites as the main platform of self-representation and communication for companies.
}

made into a resource of global investment through an assemblage of discourses, materialities, and technologies, scholars have demonstrated how farmland's role as an investable object is actively shaped, stabilized, maintained, or contested by different actors. To paraphrase Li (2014), conflicting visions of what land is and how it can or should be used shape the ways in which farmland is drawn into global circuits of capital and investment.

To date, much of this research has focused on the sociotechnical processes and practices that render farmland 'visible to finance' (Williams 2014, p. 409). For instance, scholars have investigated how practices of financial modelling, abstraction, and standardization are mobilized to 'assetize' farmland, while also pointing to the limits of such processes of assetization (Ouma 2018; Ducastel and Anseeuw 2017; Visser 2017). Others have examined the rhetorical and ideological dimensions of farmland investment, i.e., how investors legitimize and rationalize investment in farmland through, for example, discourses of food (in)security (Larder et al. 2015), notions of soil fertility (Visser 2017), or moral belief systems that define which investments are deemed 'good' and which ones are deemed 'bad' (Sippel 2018). Building on this body of literature, this present paper examines the intersections between farmland investments and the cultural and symbolic meanings of food quality-a dimension that has so far been underexamined in research on how farmland has been reconfigured into a target for investment. Taking the food safety crisis in China as a starting point, the paper highlights how investors construct, shape, and heighten specific locational and environmental characteristics of Australian farmland to appeal to Chinese quality imaginaries that associate food quality with naturalness and purity of the farming environment.

Perspectives from economic sociology and geography on how food commodities within an agri-food system become known as 'quality' offer a useful framework for studying the imaginaries underpinning Chinese investor interest in Australian farmland. This literature starts from a straightforward point of departure: a crisis of confidence in the quality and safety of mass-produced 'placeless and faceless foods' is driving consumers, and particularly those with higher incomes, to opt out from mainstream agro-industrial systems and search for alternative channels of high-quality food provisioning (Goodman 2010). In a somewhat binary opposition, the turn to quality is often described as a shift from a food system that relies on cheap, globally sourced foods to one characterized by a higher degree of local embeddedness, or, in the words of Campbell (2009), a shift from a 'food from nowhere' to a 'food from somewhere' regime. Drawing on understandings of an 'economy of qualities' (Callon et al. 2002) in which markets become reorganized around the ability of actors to qualify and position products, this literature conceptualizes 'quality' as a socially constructed category 
whose meanings are contested and changing. In her work on the politics of high-quality northeast japonica rise in China, Zader (2012), for example, maps a 'cultural economy of quality food' in which the quality of rice is constantly made and remade through material and symbolic practices by producers and consumers situated at various nodes within the agri-food system. In other words, ideas about which characteristics of a food commodity we appreciate as 'quality' are not fixed but fluid and contingent, shaped by historically and geographically diverse ideologies, resources, and agri-food relations. In addition to a focus on the shifting definitions and meanings of quality, scholarship has emphasized the close relationship between quality and the creation of value. Perceptions of quality set a food product apart from similar food commodities and enhance its distinctiveness. In the words of Guthman, perceptions of quality 'impart symbolic use value beyond the material use value of [...] food' (2004, p. 163), thereby enhancing the potential of food products to command a higher price. Consequently, quality must be understood as a 'battlefield' in which different actors compete over who gets to define quality and extract value from it. In this competition over quality, corporate agri-food actors play an increasing role. For instance, as Morgan et al. (2006) have demonstrated, $70 \%$ of organic food sales in the UK are channeled through corporate retailers. Similarly, in China, a growing number of corporate actors have identified the provision of quality food as a new niche for profit accumulation.

Insights into the strategies and practices with which actors construct meanings of quality are instructive for the analysis of Chinese farmland investments in Australia. As the literature has demonstrated, place is of key importance here. In contrast to the 'placeless and faceless' foods provided through conventional food systems, quality food provision closely links food products to specific places of production and their locational and environmental characteristics. These practices of 'territorial valorization' (Goodman 2010, p. 194) emphasize food's territorial specificity and enroll environmental qualities - both real and imaginedas elements of quality. For instance, using the French wine industry as an example, Overton and Murray (2016) demonstrate how French winemakers and retailers mobilize a discourse of terroir that explains qualitative differences in wine by appealing to the supposedly unique combination of environmental and cultural attributes-e.g., soils, climate, and artisanal traditions-which characterizes France's winemaking regions. Yet, the meanings of quality associated with particular local-environmental characteristics are not always visible to consumers. Particularly in cases where consumers are distant from the places of production, symbols, texts, and images become crucial devices in 'narrating' food's geographies and histories to consumers. Depicted on food packages or promotional materials, textual and graphical references to cultural and environmental attributes act as a 'semiotics of place' (Goodman et al. 2010, p. 10), conveying an image of locational embeddedness and distinctiveness even in extended value chains where face-to-face relationships between producers and consumers are nonexistent. In addition to such a 'semiotics of place', quality labels and certification standards are yet another way to narrate quality to distant consumers. By providing food products with 'definitional distinction' (Guthman 2004, p. 115), labels and certificates demonstrate quality in relation to product, process, and place (Ilbery et al. 2005) and distinguish the food product from other products produced in, say, less 'superior' environments or under less 'natural' conditions. In short, then, quality is constructed through imaginaries 'of not just [food's] origins but the ins and outs of how it was made and by whom in order to further fill up the meanings attached to these commodities by 'placing' them, most often, in their ecological and social contexts' (Goodman et al. 2010, p. 10).

As the following sections will demonstrate, recent Chinese investments in Australian farmland have taken place against the background of a crisis of trust in China's domestic food sector. Focusing on one case study from the dairy sector, I will examine how farmland imaginaries of naturalness, purity, and remoteness have been mobilized as key elements in the investor's strategy, yet, ironically, have also emerged as a key threat to investment success.

\section{Development trajectories in China's dairy sector: growth, crisis, and overseas investments}

Making sense of Chinese dairy investments abroad requires an understanding of the transforming meanings of dairy at home. Traditionally, dairy has not been a major component of the Chinese diet. With the exception of ethnic minorities in the Northern and Western regions of China, the majority of the country's population is lactose intolerant and, until recently, has relied on vegetables, bean products, wheat, and rice as main sources of calcium (Sharma and Zhang 2014). Indeed, throughout most of China's history, dairy has been shunned as the 'barbarian' food of China's foreign invaders (Wiley 2007). Yet today, China is the third-largest dairy producer in the world, and the average person has gone from hardly drinking any milk at all to consuming around $20 \mathrm{~kg}$ of dairy products a year (Wiley 2016). To unravel this stunning transition, we need to take a closer look at the socio-political goals linked to the promotion of dairy. Similar to the trajectory of China's meat sector described by Schneider (2017), the growth of China's dairy industry is closely associated with a political project of modernization, economic progress, and agro-industrial development. Since China opened up to global markets in the 1980s, dairy has become a symbol of China's increasingly modern and affluent society. As 
Chinese middle-class consumers look towards diversifying their diets, the government has championed dairy products for their superior health and nutrition benefits. For example, dietary policies such as school milk programs have significantly contributed to dairy's status as a normative food for children that is appreciated for its putatively positive effects on physical and intellectual growth (Wiley 2016). In other words, dairy has turned into a key element of an ongoing process of 'consumption upgrading' that has imbued dairy with cultural and symbolic meanings of progress, health, and modernity. Indeed, the Chinese government now considers the domestic dairy industry as 'indispensable for a healthy China and a strong nation' (China Government 2016), as laid out in the National Dairy Development Plan (2016-2020). At the same time, dairy production has become an important arena for the accumulation of corporate profits. Decades of agro-industrial transformation have seen the emergence of large industrial farms and dairy businesses, such as Yili and Mengniu, that now rank amongst the largest dairy corporations in the world.

The rise of China's dairy industry is not only a domestic phenomenon but has global ramifications. Since the early 2000s, a rapid increase in milk output combined with fierce competition throughout long and poorly regulated supply chains set the stage for a series of safety scandals. This safety crisis culminated in the 2008 melamine scandal, when it was revealed that a significant amount of infant formula had been adulterated with the industrial chemical melamine, leading to the death of six infants and serious illness in hundreds of thousands of babies. Since the scandal dairy imports have soared. Particularly affluent consumers have resorted to "highly privatized forms of "gated consumption"' (Hanser and $\mathrm{Li} 2015$, p. 110), i.e., the purchase of imported dairy products with the aim to insulate themselves from the safety and quality issues that beset China's domestic dairy sector.

The rise of imported dairy products, which today account for $35.5 \%$ of the Chinese domestic market, has caused much controversy within China (Chen et al. 2018b). Chinese industry experts have voiced concerns about the competitive impact of foreign dairy products on China's domestic dairy industry and have called for strengthening the quality and safety of domestically produced milk (Chen et al. 2018a; Zhang 2018). To rehabilitate trust in the domestic dairy industry, state authorities have taken significant measures, including the implementation of the 2008 Dairy Consolidation and Development Program aimed at enhancing quality and monitoring standards throughout the industry or the introduction of a nation-wide Food Safety Law in 2009 (DuBois 2018). However, while dairy quality standards have improved considerably in recent years, consumers remain sceptical of domestically produced dairy products, a recent report published by Xinhua News confirmed (Zhang et al. 2019), thus providing a window of opportunity for imported dairy brands that can leverage their 'foreignness' and associated attributes of safety and quality.

The 'crisis of trust' has spurred the global integration of China's dairy sector from two ends. On the one end, foreign firms have sought to capitalize on Chinese demand for foreign brands by directly marketing their dairy products on the Chinese market. Many foreign dairy firms such as US-based Mead Johnson or Swiss dairy giant Nestlé have supported their growing market presence in China with major investments in Chinese dairy manufacturing assets or established partnerships with domestic dairy companies. On the other end, Chinese firms have begun to expand their presence globally through investments across the entire dairy supply chain, including dairy farming, processing, and branding. In Australia, for example, investors from China have acquired dairy farms and processing plants involved in the production of milk powder, infant formula, and liquid milk (see Table 1), often with the goal of exporting these products to China, where Australian dairy enjoys a high reputation for its quality and safety. Naturally, Australians have not been passive bystanders. Indeed, perceptions of Australian dairy as a premium choice are not simply a result of its foreignness but have explicitly been nurtured by the Australian dairy industry, which has been emphasizing the "clean, natural environment in which we rear our animals, our pasturebased feeding systems and the rigorous quality and safety standards that are maintained by our farmers and processors' (Dairy Australia 2013, p. 6) in order to strengthen the competitiveness of Australia's dairy industry in global dairy trade. As the next sections demonstrate, these images are incorporated and mobilized as key devices in the strategies of Chinese investors acquiring Australian farmland.

\section{A Chinese manufacturer turned dairy farmer}

In early 2016, a story made headlines in the Australian media. A little-known Chinese investment firm registered under the name of Moon Lake Investments had acquired one of Australia's most iconic dairy firms-the Van Diemen's Land Company (VDL). Comprised of 25 individual dairy farms with 17,890 cows and covering more than 7062 hectares of farmland on the northwestern tip of Tasmania, VDL is considered the largest dairy business in the southern hemisphere. Given its scale and significance for the Australian dairy industry, VDL's offering had caused a stir of interest amongst Australian industry professionals and investment groups. Hence, it came as surprise to many when in March 2017, Australia's foreign investment authority, the Foreign Investment Review Board (FIRB), announced that it had approved a 280 million AUD investment proposal by industry outsider Moon Lake Investments. The story of Moon Lake Investments' farmland acquisition has unique 


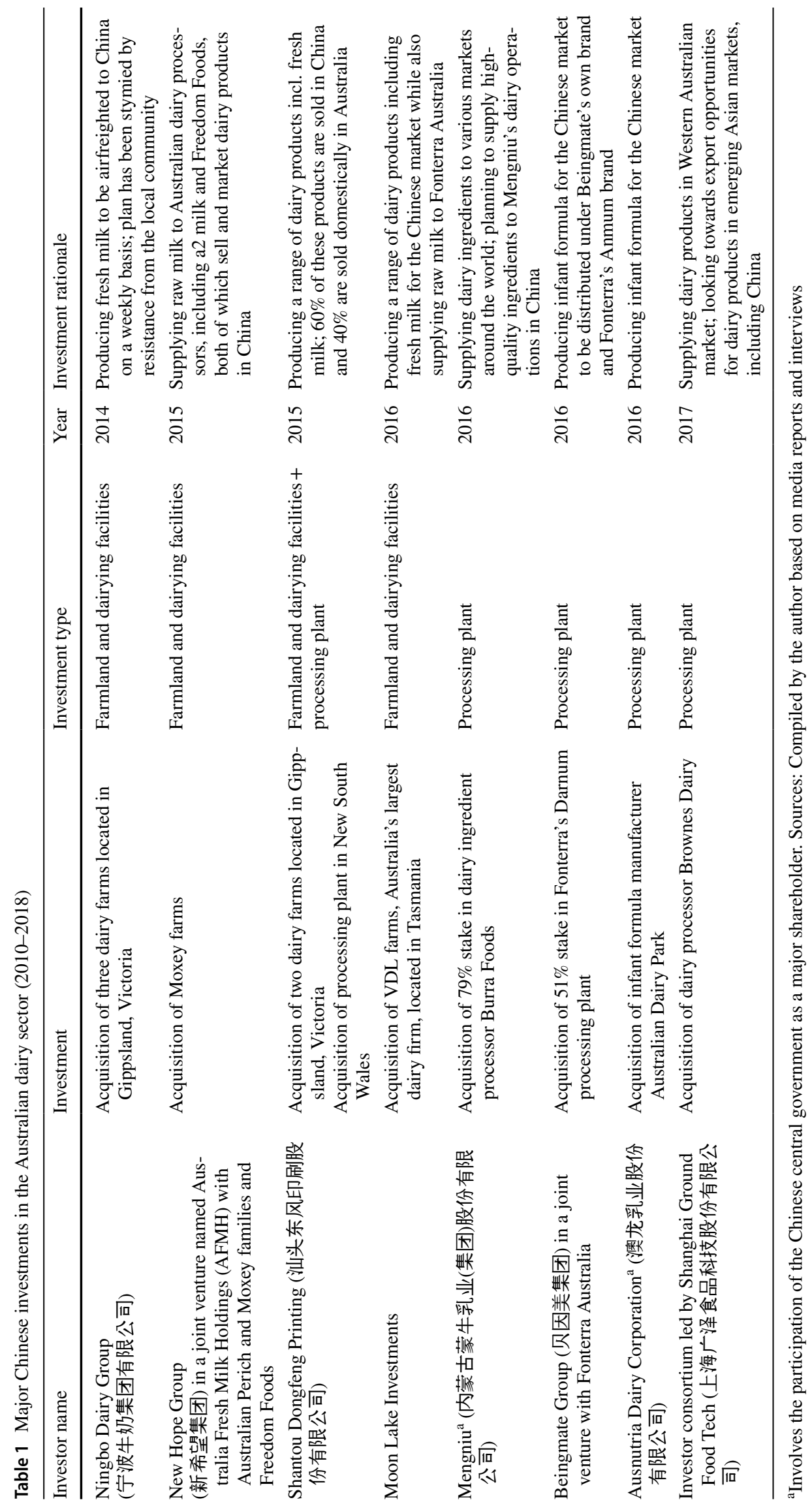


characteristics, yet it also provides a paradigmatic case of Chinese investors seeking to capitalize on the particular imaginaries of quality and safety that have emerged in China's domestic dairy market.

Embedded in a complex web of corporate structures, Moon Lake Investments' ultimate ownership is linked to a private Chinese entrepreneur, Lu Xianfeng, founder and chairman of a window blind manufacturing company in Ningbo, Zhejiang Province. When I interviewed company executives in China about the curious decision to shift the company's business focus from window blind manufacturing to dairy farming, it soon became clear that changing sociocultural meanings of milk, quality, and safety are seen as a new profit opportunity for Chinese companies faced with decreasing profitability in their traditional sectors of activity. With rising living standards, my interlocutors explained, consumers are looking for higher quality and safer dairy foods. By investing in overseas farmland sites associated with high-quality, safe dairy production, investors could effectively tap into this demand. Importantly, as a newcomer with no background in dairy farming, executives see little opportunity for the company to compete with China's domestic dairy giants for consumers in the low and mediumend markets but view the provision of premium milk to highend consumers as a niche market in which the company can establish itself.

In line with its goal to provide premium Australian milk to affluent Chinese consumers, the company pursues an 'own-operate' investment strategy. ${ }^{2}$ It has established its own operation entity - the VAN Dairy Group ${ }^{3}$ - and employs a team of local farm managers to manage day-to-day farm operations. Strategic decisions are coordinated in close collaboration with the company's central management team and chairman. Despite the company's focus on the marketing and sale of premium dairy in China, the core part of its business continues to involve supplying Australia's domestic market with raw milk. Simultaneously, the company has begun to build its export capacity for the Chinese market. At the time of my interviews, VAN Dairy processed around $10 \%$ of its raw milk output into fresh liquid milk for export to China. Marketed under the newly established VAN brand, 15,000 L of pasteurized and packaged fresh milk are air-freighted on a weekly basis to China, a share that the company is eager to grow significantly over the coming years. In just four days,

\footnotetext{
2 This paragraph is based on interviews conducted with company executives in Australia and China between 2017 and 2018, including interview 49, 5 September 2017; interview 53, 20 September 2017; interview 69, 17 May 2018; interview 80, 3 July 2018; interview 91, 17 December 2018.

${ }^{3}$ In the remainder of the article, I will refer to the investor company as 'VAN Dairy' rather than 'Moon Lake Investments' - the name of the investment vehicle used for the acquisition.
}

raw milk from the company's dairy farms in Tasmania is processed, shipped, and distributed to high-end supermarkets and affluent households across China, selling at a price premium three to four times that of domestically produced fresh milk. Furthermore, the company has begun to convert three of VDL's dairy farms into organic farms. In 2018, it obtained organic certification for the Chinese market and was simultaneously undergoing a certification process for Australia's domestic market. The certification will be used to expand the VAN product line to include organically certified ultra-high temperature (UHT) milk, yoghurts, and other premium dairy products.

\section{The Van Diemen's Land Company: investing in the 'purest milk on earth'}

As the previous sections have demonstrated, the acquisition of the Van Diemen's Land Company has taken place against the backdrop of repeated food safety scares and a crisis of trust in the quality and safety of domestically produced dairy products in China. As a result, higher income consumers in China have begun to favor imported dairy products from countries considered to possess safe, clean, and natural environments for dairy provision. In this context, Chinese investors value Australian farmland not only for its productive capacity but also for a set of locational and ecological features closely associated with meanings of quality. This section highlights how locational characteristics are used as a prime device in VAN Dairy's strategy to establish itself as a provider of premium milk in the Chinese market, but, paradoxically, also pose a threat to the rationale underpinning the company's investment strategy.

\section{Farmland and the construction of quality imaginaries}

A bold statement underpins VAN Dairy's marketing strategy in China: its customers, the company claims, drink "milk from the purest place on earth'. For customers eager to find out what is behind this claim, the company website explains:

We travelled the world to find the purest place on earth, and we found it here in northwest Tasmania. This region is ideally suited to dairy farming, with a temperate climate, clean and abundant rainfall, moderate temperatures and [...] the world's cleanest air. ${ }^{4}$

While 'the purest place on earth' appears to be a bold claim, Tasmania's natural environment is arguably more

\footnotetext{
4 VAN Dairy's English-language website, available at http://vanda iry.com.au/EN.
} 
pristine than many other places in the world. As an island state disconnected from the Australian mainland, Tasmania is renowned for its unspoiled habitats and large natural parks, covering over 40 percent of the island's territory. Abundant rainfall and a mild climate make Tasmania particularly suitable for agriculture. Indeed, over the past decades, Tasmanian farmers have drawn on the island's unique locational characteristics to cultivate an image of naturalness that has helped transform Tasmania into a 'brand' renowned for its high-quality and pure agricultural products.

Depictions of naturalness also play a key role in VAN Dairy's marketing strategy. Images of green, lush pastures, blue oceans, and pristine coastlines portray the company's 'stunning farmland' as a site of untamed, natural beauty unspoiled by the heavy hand of agricultural intervention. In the company's promotional literature, we can read stories of cows 'drinking pure water, eating fresh grass, $[\ldots]$ and living a happy life in a superior environment'. ${ }^{5}$ The central image that emerges from these accounts is one of a natural state in which dairy farming is sustainably embedded in local ecologies. Strategies that idealize the company's farming location and practices address popular anxieties amongst Chinese urban middle-classes about the risks of industrialized food production and are designed to appeal to a growing desire to reconnect with nature. Consequently, drinking VAN milk is presented by the company as the embodiment of a 'natural and healthy lifestyle'. Positioned as a counterpoint to the agro-industrial and intensive farming practices that characterize China's dairy sector, images of the farm's natural and pristine environment with its lush, green pastures and 'happy' cows are used to encode the company's dairy products with quality.

The image of naturalness is further reinforced by an emphasis on remoteness and geographical isolation. Indeed, located at the edge of Australia's southernmost island, few places would seem further removed from the lifeworlds of China's affluent urban consumers than the company's Tasmanian dairy farm. While remoteness has been a long-standing element in the promotion of Tasmania as a 'brand', it takes on more expansive meanings within the socio-cultural context of eating and food in China. As an island at the 'edge of the world', Tasmania not only boasts a natural but a pure farming environment, epitomized by its clean air. In VAN Dairy's promotional literature, carefully crafted representations of its farmland as a 'pollution-free paradise' are juxtaposed with images of Chinese cities enveloped in thick layers of smog. China has long been notorious for its

\footnotetext{
5 With the exception of its bilingual website, the company promotes its products primarily through its Chinese-language WeChat account. All excerpts quoted here have been translated from Chinese to English by the author.
}

heavy smog, a consequence of decades of breakneck industrialization and a heavy reliance on fossil fuels. Because smog is so visible and directly affects the everyday lives of millions of Chinese people, air pollution has become emblematic of growing popular anxieties about China's agro-industrial model of modernization and its impacts on nature, health, and the safety of food - a fact that is reflected by the sustained and heated commentary about the smog crisis expressed on China's social media and Internet platforms. Given the heightened sensitivities around air pollution, it is hardly surprising that VAN Dairy has promoted purityembodied by the farm's clean air, fresh ocean winds, and abundant rainfalls - as a prime device with which to project quality on its products. As the company's website expresses it: 'Clean air, pure rainfall, lush green pasture, it all adds up to happy, healthy cows, which means the purest, cleanest milk!' This sense of purity is also conveyed by the blue color schemes used on the company's milk carton and a website styled in hues of blue rather than, as one might assume, green. Furthermore, a curious fact has helped the company anchor a rhetoric of purity in scientific reality. Situated along the farm's northwestern coastline, an atmospheric measurement site operated by the Australian Bureau of Meteorology has been monitoring changes in the global atmosphere since the early 1970s. Taking advantage of the farm's geographical isolation, the station has been 'recording some of the cleanest air [there] that can be accessed on the planet' (Cleland et al. 2016). The station's measurement data has provided welcome scientific evidence for the company's claim to produce milk from the 'purest place on earth'.

The image of naturalness and purity promoted by the company's marketing strategy is not only instructive for what it reveals but also for what it conceals. The stunning farm landscape and 'happy' cows represent milk as 'natural', but they ignore the industrial processes through which milk becomes available as food: the milking parlors and cooling tanks necessary for harvesting the milk, the computer systems monitoring and optimizing each cow's milk output, and the fertilizers and chemicals used to encourage pasture growth all remain hidden from the gaze of the viewer. As the largest dairy business in the Southern hemisphere with more than 30,000 dairy livestock, the farm's naturalness is, indeed, an industrial one. Moreover, as the pressure to intensify production has grown in recent years, technology and scientific management practices are becoming ever more prevalent on the farm, as one farm manager told me. ${ }^{6}$ Similarly, little seems natural about how the milk ends up on the dinner tables of Chinese consumers thousands of miles away from the farm. Extended supply chains across continents and oceans connect the company's dairy farm in Tasmania

\footnotetext{
${ }_{6}$ Interview 91, 17 December 2018.
} 
with supermarkets in China's modern, urban centers. Modern technologies and infrastructures ensure that the freshly packaged milk reaches its destinations in China in just four days-travelling by ship, truck, and plane. A food traceability application using advanced digital technology has been developed by the company to help consumers 'know' about the milk's origin. By scanning a bar code on the milk carton with their mobile phones, consumers can trace the carton's entire journey from the fields of the farm to the shelves of a Chinese supermarket. Each step of the supply chain is meticulously documented, providing consumers with a 'complete grass-to-glass experience' for every carton of milk they buy, as one company executive proudly told me. ${ }^{7}$ In short, it appears that naturalness and purity—central dimensions of the company's claim of quality milk provision-are produced by the very technologies of industrial progress against which they claim to form a counterpoint.

\section{Fresh milk and the geographical limits to quality}

The carefully constructed images of naturalness and purity with which the company markets its milk in China seem to be well-suited to appeal to consumer concerns about food quality and safety. Yet, it appears that the company has been struggling to boost sales and win costumers. How can we explain the difficulties the company has been facing in establishing itself as a premium milk provider in the Chinese market? A closer look at the material and practical challenges of milk provision suggests that the very locational feature on which the company has built its business caseremoteness-also threatens to undermine it. In other words, while the farm's remoteness is at the heart of the company's ambition to provide Chinese consumers with 'milk from the purest place on earth', it simultaneously poses a formidable challenge to its realization.

As one of the world's most perishable foods, milk, especially in its fresh liquid form, is inherently limited in how far it can last over time and space. Fresh milk will spoil within hours if not refrigerated. Given its perishable nature, the geography of dairy farming has traditionally been highly localized, making milk 'the most local of all supermarket staples' (Freidberg 2010, p. 198). Despite advances in preservation technology such as the advent of ultra-high temperature (UHT) milk, dairy has, to a certain extent, defied its integration into larger circuits of global agri-food trade. At present, only $13 \%$ of global dairy production is traded internationally, mostly in preserved form as either butter, cheese, or milk powder (FAO 2019).

While for much of China's domestic dairy history, liquid milk has been consumed in the form of UHT milk, dairy

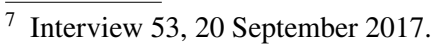

producers and industry peak bodies in China are increasingly championing fresh milk for its high nutritional value and better taste (Zhang 2017). Seen as a beacon of a modern and developed dairy industry and with profit margins at times twice as high as margins on UHT milk, the provision of fresh milk is not only transforming domestic dairy production but also the composition of dairy imports to China (OECD 2019, p. 187). Delivering fresh, liquid milk produced overseas to markets in China, however, has required a series of remarkable technological and regulatory feats. For VAN Dairy, delivering fresh milk by airplane from Tasmania to cities on China's eastern coast is dependent on a host of carefully coordinated technologies and regulatory procedures, from seamless cold chain management to rigorous food safety testing, smooth transportation links within and across national borders, as well as tightly coordinated inspection procedures to avoid import delays that would impact fresh milk's most precious attribute-its shelf life. The high costs associated with airfreighting fresh milk are reflected in the premium prices the company charges for its milk. A one-liter carton of milk currently sells for $70 \mathrm{RMB}$ - around four times the price of locally produced fresh milk sold in high-end Chinese supermarkets. ${ }^{8}$ The company does not publicly report its business figures, but interviews with marketing executives in China suggest that the high retail price constitutes a key challenge to entering the market. As one executive confirmed, 'the tricky part is $[\ldots]$ to convince consumers that our products are very, very premium and worth their price. ${ }^{9}$

It is presumably against this background that the company has begun to shift towards the provision of organically certified UHT milk. Having achieved organic certification for three of its 25 dairy farms, the company is now entitled to use China's official 'organic food' label on its milk cartons and is awaiting certification for the Australian market, too. With a shelf life of several months, UHT milk can be transported at much lower cost and with fewer risks. For organic UHT milk, claims of naturalness and purity are no longer encapsulated in milk's freshness but communicated through food labels that provide consumers with authoritative assurance about the quality of the milk they drink. Hence, the shift to the provisioning of a UHT milk product whose claim to quality now primarily rests on labeling rather than on freshness per se should, at least partially, be understood as a response to the geographical challenge that remoteness presents to the company's claim to provide 'milk from the purest place on earth'.

\footnotetext{
8 Author's field notes, 2018.

9 Interview 53, 20 September 2017.
} 


\section{Conclusion}

This paper has investigated the acquisition of one of Australia's largest dairy farms by a Chinese manufacturing company and its efforts to market 'milk from the purest place on earth' to consumers in China. Situating this case study within a crisis of trust in China's domestic dairy sector, I have argued that quality imaginaries of Australia as a producer of premium and safe dairy act as a powerful driver of Chinese investment into Australian farmland. In other words, by drawing on and adding to existing imaginaries of Australian farmland as natural and pure, investors hope to enhance perceptions of quality amongst affluent Chinese consumers looking for premium, safe alternatives to domestically produced milk. As shown by the case study presented here, claims to quality rest on a seemingly holistic imaginary of the 'farm as nature', i.e., the framing of the farm as a natural environment comprising pastures, oceans, abundant rainfall (climate), and clean air (atmosphere). This imaginary is markedly different from the celebration and fetishization of soil fertility in the discourses of investors operating in the black earth regions of Russia and Ukraine (Visser, this issue). While farmland in the black earth region is framed as a locus of highly productivist, high-yield, industrial-style agriculture, the land imaginaries identified here are built around a focus on explicitly anti-industrial values that cast farmland as 'natural' and milk as a conduit for consumers to reconnect to nature (although, as I have suggested above, this naturalness relies on strategies that actively render invisible the industrial-technological systems on which the production of milk crucially hinges).

The account presented here makes two contributions to the literature on the contemporary land rush. First, from a theoretical point of view, it emphasizes the key role of land's biophysical, material, and environmental conditions in turning land into an attractive target for investment. These findings suggest that for farmland investors land not only figures as a number on a balance sheet, an abstracted 'asset' subject to calculative practices, but as a bundle of material characteristics embodied in elements such as soil, climate, or atmosphere that can be harnessed for the accumulation of profits. While some material aspects of farmland such as soil quality, topography, or water availability may appear more 'objective' in determining land's potential profitability (Visser 2017), this paper has highlighted the importance of cultural and symbolic meanings in determining 'the uses and possibilities that matter affords to us' (ibid., pp. 187-188). For the investment project presented here, farmland's purity and naturalness are crucial not so much because there is an objective relationship between pure air and, say, high milk yields, but because the investor company operates within a cultural context in which meanings of quality are associated with air pollution and, hence, provide legitimacy for the company's marketing claim that pure air means 'the purest, cleanest milk'. Yet, land's materiality can also turn into an obstacle to the realization of profits. As the case study presented here has demonstrated, while geographical remoteness is at the heart of land imaginaries as natural and pure, fresh milk's biophysical characteristics make it a stubbornly local food that is inherently limited in how far it can travel across time and space. Hence, a material aspect such as farmland location can become both a prized advantage and a looming risk to investment viability.

Second, the paper provides a new empirical perspective on the role and significance of capital flows from China within the global land rush. Much of the literature to date has linked Chinese overseas farmland investment to state-led efforts to fulfill long-term food security objectives (McMichael 2013; Thomas 2013). While this paper does not contest the growing importance of a global perspective in policythinking on national food security amongst Chinese officials and researchers, the link between overseas farmland investment and national food security appears to be more complex and multilayered than is often suggested. Indeed, as the case investigated here suggests, individual investors may be motivated more by the profit opportunities presented by the cultural economy of 'quality food' rather than by a desire to 'feed the nation'. Rather than assuming that investments from China are governed by a single, coherent logic, more emphasis must be placed on the 'contingency and contextuality' (Williams 2014, p. 408) of individual land deals and the multiple and variegated processes through which farmland is enrolled in the investment strategies of a diverse set of Chinese actors. Moreover, these investment strategies do not arise out of 'thin air' but are grounded in specific socio-cultural contexts that produce and assign shifting meanings to food. As the paper has demonstrated, the quality imaginaries that have attracted investors to Australia cannot be studied in isolation from the domestic discourses on safety, health, modernity, or social status that are shaping the foodways and eating habits of Chinese consumers. While imaginaries of Australian farmland as clean, green, and pure have long been prominent in the marketing strategies of Australia's domestic farm sector, the powerful appeal of these images to Chinese investors and consumers alike can only be explained by a perspective that takes into account the shifting socio-cultural meanings of food in China. Lastly, this cultural perspective also reminds us that farmland investments are transforming both the social relations of production and consumption; hence, a critical analysis of the social outcomes of farmland investment must not only focus on how inflows of Chinese capital transform land, labor, and production in recipient countries but also on the potential of 
such investments to exacerbate the highly unequal relations of consumption underlying the provisioning of imported, safe quality food to consumers in China.

Funding Open Access funding enabled and organized by Projekt DEAL. The funding was provided by Deutsche Forschungsgemeinschaft (DE) (Grant No. SFB 1199, sub-project C04).

Open Access This article is licensed under a Creative Commons Attribution 4.0 International License, which permits use, sharing, adaptation, distribution and reproduction in any medium or format, as long as you give appropriate credit to the original author(s) and the source, provide a link to the Creative Commons licence, and indicate if changes were made. The images or other third party material in this article are included in the article's Creative Commons licence, unless indicated otherwise in a credit line to the material. If material is not included in the article's Creative Commons licence and your intended use is not permitted by statutory regulation or exceeds the permitted use, you will need to obtain permission directly from the copyright holder. To view a copy of this licence, visit http://creativecommons.org/licenses/by/4.0/.

\section{References}

Appadurai, A. 1986. Introduction: Commodities and the politics of value. In The social life of things, ed. A. Appadurai, 3-63. Cambridge: Cambridge University Press.

Belesky, P., and G. Lawrence. 2018. Chinese state capitalism and neomercantilism in the contemporary food regime: Contradictions, continuity and change. The Journal of Peasant Studies. https ://doi.org/10.1080/03066150.2018.1450242.

Brautigam, D. 2015. Will Africa feed China?. Oxford: Oxford University Press.

Brautigam, D., and H. Zhang. 2013. Green dreams: Myth and reality in China's agricultural investment in Africa. Third World Quarterly 34 (9): 1676-1696.

Callon, M., C. Méadel, and V. Rabeharisoa. 2002. The economy of qualities. Economy and Society 31 (2): 194-217.

Campbell, H. 2009. Breaking new ground in food regime theory: Corporate environmentalism, ecological feedbacks and the 'food from somewhere' regime? Agriculture and Human Values 26: 309-319.

Chen, B., S. Chen, Z. Cao, Y. Yao, and Q. Yan. 2018a. 2017年国际 奶业形势分析与展望 [Analysis and outlook of the international dairy industry in 2017]. 中国牛奶 [Dairy Economy] (4): 52-60.

Chen, B., S. Chen, Q. Yan, Y. Yao, and Z. Cao. 2018b. 2017年度奶业 贸易分析报告 [2017 China Dairy Trade Analysis Report]. 中国 奶牛 [Dairy Economy] (3): 55-63.

China Government. 2016. 全国奶业发展规划(2016 2020 年) [National Dairy Development Plan (2016 - 2020)]. https://www. miit.gov.cn/n1146295/n1652858/n1652930/n3757019/c5458461/ part/5458472.doc. Accessed 24 Feb 2020.

Cleland, S., M. Keywood, P. Fraser, and P. Krummel. 2016. Forty years of measuring the world's cleanest air reveals human fingerprints on the atmosphere.https://theconversation.com/forty-years-ofmeasuring-the-worlds-cleanest-air-reveals-human-fingerprintson-the-atmosphere-68489. Accessed 26 April 2019.

Cook, I., and P. Crang. 1996. The world on a plate: Culinary culture, displacement and geographical knowledges. Journal of Material Culture 1 (2): 131-153.
Cotula, L. 2012. The international political economy of the global land rush: A critical appraisal of trends, scale, geography and drivers. The Journal of Peasant Studies 39 (3-4): 649-680.

Dairy Australia. 2013. Trade and the Australian dairy industry.

DuBois, T.D. 2018. China's dairy industry going big. https://www.asiag lobalonline.hku.hk/china-dairy-industry-going-big/. Accessed 27 Aug 2018.

Ducastel, A., and W. Anseeuw. 2017. Agriculture as an asset class: Reshaping the South African farming sector. Agriculture and Human Values 34: 199-209.

Edelman, M., C. Oya, and S.M. Borras Jr. 2013. Global land grabs: Historical processes, theoretical and methodological implications and current trajectories. Third World Quarterly 34 (9): $1517-1531$.

FAO. 2019. Gateway to dairy production and products.https://www. fao.org/dairy-production-products/socio-economics/markets-andtrade/en/. Accessed 6 May 2019.

Freidberg, S. 2010. Fresh. A perishable history. Cambridge: Belknap Press.

Gooch, E., and F. Gale. 2018. China's foreign agriculture investments. EIB-192.

Goodman, D. 2010. Place and space in alternative food networks: Connecting production and consumption. In Consuming space: Placing consumption in perspective, ed. M.K. Goodman, D. Goodman, and M. Redclift, 189-211. London: Routledge.

Goodman, M.K., D. Goodman, and M. Redclift. 2010. Introduction: Situating consumption, space and place. In Consuming space: Placing consumption in perspective, ed. M.K. Goodman, D. Goodman, and M. Redclift, 3-40. London: Routledge.

Guthman, J. 2004. Agrarian dreams. The paradox of organic farming in California. California studies in critical human geography, vol. 11. Berkeley, CA, London: University of California Press.

Hanser, A., and J.C. Li. 2015. Opting out? Gated consumption, infant formula and China's affluent urban consumers. The China Journal 74: 110-128.

Ilbery, B., C. Morris, H. Buller, D. Maye, and M. Kneafsey. 2005. Product, process and place: An examination of food marketing and labelling schemes in Europe and North America. European Urban and Regional Studies 12 (2): 116-132.

Klein, J.A. 2013. Everyday approaches to food safety in Kunming. The China Quarterly 214: 376-393.

KPMG. 2013. Demystifying Chinese investment in Australian agribusiness. Important choices to be made.

Larder, N., S.R. Sippel, and G. Lawrence. 2015. Finance capital, food security narratives and Australian agricultural land. Journal of Agrarian Change 15 (4): 592-603.

Lawrence, G., S.R. Sippel, and N. Larder. 2019. State-led and finance-backed farming endeavours: Changing contours of investment in Australian agriculture. In Finance or food? The role of cultures, values, and ethics in land use negotiations, ed. Hilde Bjørkhaug, Philip McMichael, and Bruce Muirhead, 150-177. Toronto: University of Toronto Press.

Li, T.M. 2014. What is land? Assembling a resource for global investment. Transactions of the Institute of British Geographers 39 (4): 589-602.

McMichael, P. 2013. Land grabbing as security mercantilism in international relations. Globalizations 10 (1): 47-64.

Morgan, K., T. Marsden, and J. Murdoch. 2006. Worlds of food. Place, power, and provenance in the food chain. Oxford: Oxford University Press.

OECD. 2019. OECD-FAO Agricultural Outlook 2019-2028. OECDFAO Agricultural Outlook. Paris: OECD Publishing.

Oliveira, GdeLT. 2018. Chinese land grabs in Brazil? Sinophobia and foreign investments in Brazilian soybean agribusiness. Globalizations 15 (1): 114-133. 
Oliveira, GdeLT, and M. Schneider. 2015. The politics of flexing soybeans: China, Brazil and global agroindustrial restructuring. The Journal of Peasant Studies. 2: 89. https://doi. org/10.1080/03066150.2014.993625.

Ouma, S. 2014. Situating global finance in the land rush debate: A critical review. Geoforum 57: 162-166.

Ouma, S. 2018. Opening the black boxes of finance-gone-farming: A global analysis of assetization. In The financialization of agrifood systems: Contested transformations, eds. H. Bjørkhaug, A. Magnan and G. Lawrence, 85-107. Earthscan food and agriculture series. Abingdon: Routledge.

Overton, J., and W.E. Murray. 2016. Fictive place. Progress in Human Geography 40 (6): 794-809.

Schneider, M. 2017. Dragon head enterprises and the state of agribusiness in China. Journal of Agrarian Change 17 (1): 3-21.

Scoones, I., R. Hall, S.M. Borras Jr., B. White, and W. Wolford. 2013. The politics of evidence: Methodologies for understanding the global land rush. The Journal of Peasant Studies 40 (3): 469-483.

Sharma, S., and R. Zhang. 2014. China's dairy dilemma. The evolution and future trends of China's dairy industry. Global Meat Complex: The China Series.

Sippel, S.R. 2018. Financialising farming as a moral imperative? Renegotiating the legitimacy of land investments in Australia. Environment and Planning A: Economy and Space 50 (3): 549-568.

Thomas, N. 2013. Going out: China's food security from Southeast Asia. The Pacific Review 26 (5): 531-562.

Visser, O. 2017. Running out of farmland? Investment discourses, unstable land values and the sluggishness of asset making. Agriculture and Human Values 34: 185-198.

Wiley, A.S. 2007. Transforming milk in a global economy. American Anthropologist 109 (4): 666-677.

Wiley, A.S. 2016. Re-imagining milk. Cultural and biological perspectives, 2nd ed. London: Routledge.

Williams, J.W. 2014. Feeding finance: A critical account of the shifting relationships between finance, food and farming. Economy and Society 43 (3): 401-431.

Wolford, W., S.M. Borras Jr., R. Hall, I. Scoones, and B. White. 2013. Governing global land deals: The role of the state in the rush for land. Development and Change 44 (2): 189-210.
Yan, Y. 2012. Food safety and social risk in contemporary China. The Journal of Asian Studies 71 (3): 705-729.

Zader, Amy. 2012. Understanding quality food through cultural economy: The 'politics of quality' in China's northeast japonica rice. Agriculture and Human Values 29 (1): 53-63.

Zhang, X. 2017. 国家优质乳核心标准发布中国奶业加速进入巴氏 鲜奶时代 [National high-quality milk core standards released. China's dairy industry speeds up its entry into the era of pasteurized milk]. Xinhua. 22 August 2007. https://www.xinhuanet.com/ food/2017-08/22/c 1121523202.htm. Accessed 2 Mar 2020.

Zhang, Y. 2018. 国产奶就是优质奶, 进口奶只是补充 [Domestic milk is high-quality milk, imported milk is just a supplement]. dac. org.cn/read/newzjlt-18102310222240910803.jhtm. Accessed 24 Feb 2020.

Zhang, L., J. Wang, and J. Wei. 2019. 乳品"高质量"、市场"低信 心": 如何驱散中国乳业"历史阴影"? [High-quality dairy and low market confidence: How to dispel the shadows of China's dairy history?]. Xinhua. 10 December 2019. https://www.xinhu anet.com/fortune/2019-12/10/c_1125328457.htm. Accessed 24 Feb 2020.

Publisher's Note Springer Nature remains neutral with regard to jurisdictional claims in published maps and institutional affiliations.

Michaela Böhme is a $\mathrm{PhD}$ candidate at the Collaborative Research Center 'Processes of Spatialization under the Global Condition' (SFB 1199) at Leipzig University, where she also completed her MA in Global Studies with an area studies focus on China. Set against the background of China's deepening integration into the global agri-food system, her doctoral research explores the entangled interests and motive forces shaping Chinese investments in Australian agriculture. She is also interested in the political economy of China's development, broader issues of multipolarity, and the globalization of food and agriculture. 